Article

\title{
Thermal Death Kinetics of Cryptolestes pusillus (Schonherr), Rhyzopertha dominica (Fabricius), and Tribolium confusum (Jacquelin du Val) Using a Heating Block System
}

\author{
Lixia Hou ${ }^{1}$, Yi Wu ${ }^{2}$ and Shaojin Wang ${ }^{1,3, *}$ \\ 1 College of Mechanical and Electronic Engineering, Northwest A\&F University, Yangling, Shaanxi 712100, \\ China; hlx0924hyx@163.com \\ 2 Academy of State Administration of Grain, Beijing 100037, China; wuyi@chinagrain.org \\ 3 Department of Biological Systems Engineering, Washington State University, 213 L.J. Smith Hall, Pullman, \\ WA 99164-6120, USA \\ * Correspondence: shaojinwang@nwsuaf.edu.cn; Tel.: +86-29-8709-2391; Fax: +86-29-8709-1737
}

Received: 24 March 2019; Accepted: 24 April 2019; Published: 26 April 2019

check for updates

\begin{abstract}
Thermal treatment has been extensively used to control pests in stored grains for a long time. The objective of this study was to analyze thermal death kinetics of adult flat grain beetle, Cryptolestes pusillus (Schonherr), lesser grain borer, Rhyzopertha dominica (Fabricius), and confused flour beetle, Tribolium confusum (Jacquelin du Val), using a heating block system (HBS), at temperatures of 46, 48, 50 , and $52{ }^{\circ} \mathrm{C}$ for $\mathrm{C}$. pusillus and T. confusum, and $48,50,52$, and $54{ }^{\circ} \mathrm{C}$ for $R$. dominica with a heating rate of $5{ }^{\circ} \mathrm{C} / \mathrm{min}$. Thermal death curves of those three insects followed a 0th-order reaction model. Complete mortality of $C$. pusillus, $R$. dominica, and T. confusum were observed after exposure to 1.4, 5.0, and $0.9 \mathrm{~min}$ at 52,54 and $52{ }^{\circ} \mathrm{C}$, respectively. The thermal death activation energy for controlling C. pusillus, $R$. dominica, and T. confusum was $689.91,380.88$, and $617.08 \mathrm{~kJ} / \mathrm{mol}$ with $z$ values of 2.88 , 5.18 , and $3.22{ }^{\circ} \mathrm{C}$, respectively. The cumulative lethal time model can also be used to predict mortality of these three insects during a practical heating process. The information provided by this study on storage pests may be useful for developing effective thermal treatment protocols.
\end{abstract}

Keywords: storage insect; thermal treatment; thermal death time model; cumulative lethal time model

\section{Introduction}

Flat grain beetle, Cryptolestes pusillus (Schonherr), lesser grain borer, Rhyzopertha dominica (Fabricius), and confused flour beetle, Tribolium confusum (Jacquelin du Val), are major pests of stored products worldwide [1-3]. They infest stored grain, beans, nuts, and oil seeds, and could create feeding holes on kernels. Insect infestations of kernels reduce nutritional values, germination rates, and market prices of stored grain, and cause great economic losses to farmers. Therefore, it is necessary to develop effective methods to control these storage pests. Pesticides and fumigants have been widely used to disinfest agricultural products due to their effectiveness and low cost [4]. With increased insect resistance to chemicals and concerns for environmental pollutions, and food safety requirements, there have been renewed efforts to investigate non-chemical insect control methods [5,6].

Thermal treatments are one of the most popular physical treatments to control pests in agricultural products due to their easy applications and non-chemical characteristics [7-9]. Before thermal treatment is implemented, the lethal conditions of insects need to be determined because they are changing with different species and life stages [10]. At 45 and $50{ }^{\circ} \mathrm{C}$ water bath treatment, 35 and $2 \mathrm{~h}$ exposure times were required to control C. pusillus, respectively [11]. When wheat was exposed to infrared radiation 
for $24 \mathrm{~h}, 99 \%$ mortality of $R$. dominica was achieved [12]. Using a grain heating apparatus, $\mathrm{LT}_{99.9}$ values of $R$. dominica were between $2.49 \mathrm{~h}$ and $78.22 \mathrm{~h}$ at treatment temperatures of 53 and $45^{\circ} \mathrm{C}$ [13]. After heating for $36 \mathrm{~h}$ with 77 electric heaters at $20 \mathrm{~kW} / \mathrm{h}$ of power, $100 \%$ mortality of adult $R$. dominica and T. confusum was obtained in a whole flour mill [14]. Such a long heating time required to achieve complete mortality of insects could be caused by slow conventional heat transfer and poor heating uniformity in host materials. Therefore, lethal conditions determined by these methods might be not suitable for rapid microwave and radio frequency (RF) heating. The lethal parameters obtained by the slow or non-uniform heating conditions would result in either insect survivals or product damage in practical thermal treatments. Other researchers reported that holding time for achieving $100 \%$ mortality was $1 \mathrm{~min}$ at $52{ }^{\circ} \mathrm{C}$ for Plodia interpunctella [15], 4 min at $50{ }^{\circ} \mathrm{C}$ for Sitophilus oryzae [16], 4 min at $52{ }^{\circ} \mathrm{C}$ for Sitophilus zeamais [17], and $1.3 \mathrm{~min}$ at $52{ }^{\circ} \mathrm{C}$ for Tribolium castaneum [18], when heated directly by a heating block system (HBS). These lethal times determined by the HBS were validated using RF treatments. Complete mortality of adult $S$. oryzae infesting milled rice using RF energy with heating rate of $6.1^{\circ} \mathrm{C} / \mathrm{min}$ was obtained at $50{ }^{\circ} \mathrm{C}$ for holding $6 \mathrm{~min}$ with hot air [19]. Furthermore, $100 \%$ mortality of $T$. castaneum larvae infesting the rapeseeds was achieved with RF treatment at the heating rate of $4.4^{\circ} \mathrm{C} / \mathrm{min}$ attaining $55^{\circ} \mathrm{C}$ without a holding time [20]. The lethal parameters obtained for some insects cannot be applied to other pest spp. without resulting in treatment failures. Therefore, it is necessary to determine the lethal conditions for controlling storage insects, such as C. pusillus, R. dominica, and T. confusum, using RF energy.

Different statistical models have been used to predict the mortality of insects during thermal treatment. Thermal death kinetic (TDK) model is used to successfully predict mortality of insects during isothermal stage when the insects are heated directly by the HBS [17,18]. Cumulative lethal time model calculates the accumulated lethal effect of heating process and holding period by the measured temperature-time history and was used to predict mortality of Cydia pomonella in cherries when they were subjected to hot water treatment [21]. Therefore, these two models were used to predict the mortality of insects in this paper.

Since $R$. dominica complete their development inside grain kernels, it is difficult to get internal stages, such as larvae and pupae, for treatments without influencing survival ratio of tested insects. In addition, hand-processing would largely influence survival ratio of eggs and larvae without using host grains for these storage insects. Furthermore, the heating treatments for adult stages in grains are easier to apply, and evaluation of insect survival ratio is immediate and reliable. Therefore, adult stage could be selected to conduct thermal death kinetic studies.

The aims of this study were: (1) to determine thermal survival ratio of adult C. pusillus, R. dominica, and T. confusum at four selected temperatures and different exposure times using the HBS; (2) to develop thermal death kinetic models and calculate activation energy of these three storage insects; (3) to establish mortality curves by a cumulative lethal time model; and (4) to compare the lethal times and kinetic parameters of the three insects to those of other storage pests.

\section{Materials and Methods}

\subsection{Treatment Procedure}

C. pusillus, R. dominica, and T. confusum were reared at the Academy of State Administration of Grain, Beijing, China, and obtained in July 2017. C. pusillus and T. confusum were reared on $60 \%$ wheat flour, $30 \%$ oats, and $10 \%$ yeast by weight. $R$. dominica was reared on whole wheat $(14 \pm 1 \%$, w.b.). All the species were contained in glass rearing bottles $(9 \mathrm{~cm}$ diameter $\times 10 \mathrm{~cm}$ height $)$ sealed with filter papers for air exchange, and maintained at $28 \pm 1{ }^{\circ} \mathrm{C}$ and $63 \% \mathrm{RH}$ in a constant temperature and humidity incubator (HWS-350, Hangzhou Aipu Instrument Co., LTD, Hangzhou, China). The adult insects with rearing mixture were separated by a Chinese standard sieve $\# 40$ and collected by a glass petri dish (20 cm diameter). 
To obtain survival ratio of different storage insects, the HBS was used, whereby test insects could be heated to target temperatures with heating rates from $0.1^{\circ} \mathrm{C} / \mathrm{min}$ to $15^{\circ} \mathrm{C} / \mathrm{min}$. The system was composed of top and bottom heating blocks, two heating pads, an insect chamber $\left(214 \times 214 \times 3 \mathrm{~mm}^{3}\right)$, temperature sensors, and a data acquisition/control unit (Figure 1). Two block temperatures were measured and collected by two type-T thermocouple sensors (TMQSS-020U-12, Omega Engineering, INC., Norwalk, CT, USA). Heating rate, heating temperature or target temperature, and exposure time, were governed by custom-developed software and proportional-integral-derivative (PID) controllers (i/32 temperature \& process controller, Omega Engineering Inc., Norwalk, CT, USA) through a solid-state relay. More information about the HBS can be found elsewhere [22].

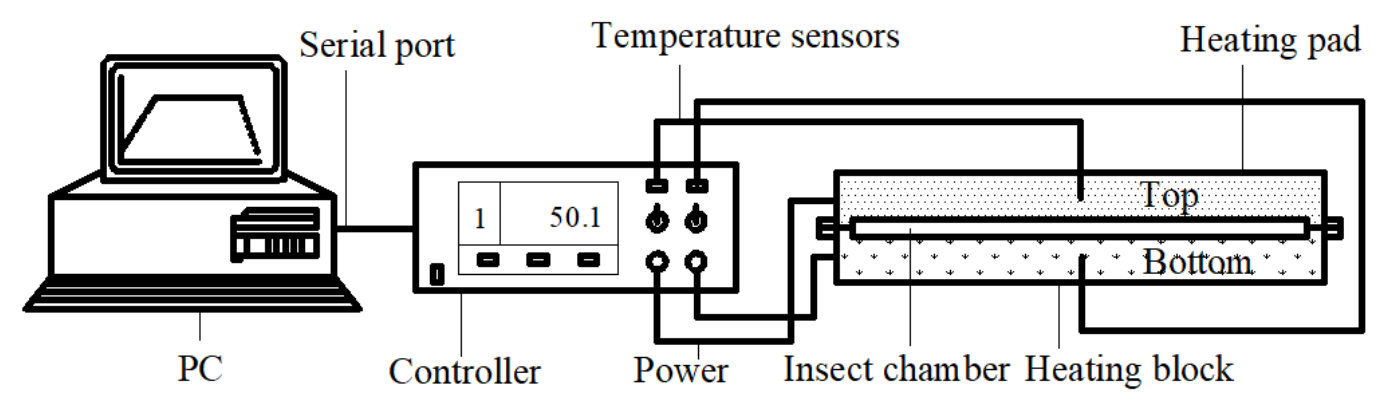

Figure 1. Schematic diagram of heating block system for insect mortality experiments [22].

Based on lethal conditions of S. oryzae [16], S. zeamais [17], and T. castaneum [18], and preliminary experiments, five exposure times (0.3-150 min for T. confusum and 0.2-60 min for C. pusillus) at 46, 48,50 , or $52{ }^{\circ} \mathrm{C}$ with heating rate of $5^{\circ} \mathrm{C} / \mathrm{min}$ were chosen to offer a survival ratio from $0 \%$ to $100 \%$. For $R$. dominica, five heating times $\left(1-75 \mathrm{~min}\right.$ ) at $48,50,52$, and $54{ }^{\circ} \mathrm{C}$, and the heating rate of $5{ }^{\circ} \mathrm{C} / \mathrm{min}$ were selected. Control insects were put into the unheated HBS for $60 \mathrm{~min}$ for C. pusillus, $75 \mathrm{~min}$ for $R$. dominica, and $150 \mathrm{~min}$ for $T$. confusum, which was equivalent to the longest exposure time for each species among the thermal treatments.

To prevent escape of test insects and provide fast extraction from insect chamber, 50 insects were sealed in a nylon-mesh bag $(15 \times 10 \mathrm{~cm})$ before this was directly placed on the center of the insect chamber. After the bottom heating block was covered with the top one, the treatment program began to run. Once the thermal treatment was finished, test insects were moved to rearing bottles, which were placed under rearing conditions until survival ratio of treated insects was calculated. Since the height of insect chamber was only $3 \mathrm{~mm}$, the heat transfer effect of the nylon-mesh bag on the insect mortality was negligible [16]. Survival ratio of insects was calculated in $48 \mathrm{~h}$ after thermal treatment. The insects were considered as dead if the insect was not moving or had no any response to a light probe.

\subsection{Mortality Models}

Survival ratio (\%) of treated insects is an important indicator to evaluate effect of thermal treatment and described as the ratio of surviving insects $(N)$ to initial numbers of insects $\left(N_{0}\right)$ :

$$
S=\frac{N}{N_{0}} \times 100 \%
$$

A fundamental kinetic model, i.e., thermal death time (TDT) kinetic model, was applied to describe the survival ratio of adult C. pusillus, R. dominica, and T. confusum under isothermal treatments and to predict lethal time (LT) at different temperature and survival ratio. According to the TDT kinetic model, the survival ratio of insects and heating time at a certain temperature followed the relationship of Equation (2):

$$
\frac{d\left(N / N_{0}\right)}{d t}=-k\left(N / N_{0}\right)^{n}
$$


where $t$ is the exposure time ( $\mathrm{min}$ ) at certain temperature. $k$ means the thermal death rate constant $(1 / \mathrm{min})$, and $n$ expresses the kinetic order of reactions. Taking the integration of both sides of Equation (2), the survivor ratio as a function of exposure time can be solved with different reaction orders and described as Equation (3):

$$
\begin{array}{cc}
\ln \left(N / N_{0}\right)=-k t+c & (n=1) \\
\left(N / N_{0}\right)^{1-n}=-k t+c & (n \neq 1)
\end{array}
$$

For each temperature, a linear regression was used to analyze survival ratio and exposure time $(t)$ on the basis of Equation (3) for the reaction orders of $0,0.5,1,1.5$, and 2. The most suitable reaction order was determined by comparing the average coefficients of determination $\left(R^{2}\right)$ over four heating temperatures. Once the reaction order was fixed, the constant values of $k$ and $c$ were obtained from the regression equation. Then, the best kinetic model was applied to predict the $\mathrm{LT}_{95}, \mathrm{LT}_{99}, \mathrm{LT}_{99.33}$, $\mathrm{LT}_{99.99}$ and $95 \%$ confidence interval (CI) for each heating temperature.

TDT curves for adult C. pusillus, $R$. dominica, and T. confusum were obtained by drawing the minimum exposure time needed to obtain $0 \%$ survival ratio of insects at each treated temperature on a semi-logarithmic coordination. The $z$ value was calculated as the negative reciprocal of the slope of the TDT curve. Then, the activation energy $\left(E_{a}, \mathrm{~J} / \mathrm{mol}\right)$ was applied to investigate the sensitivity of treated insects to temperature changes and can be estimated by Equation (4):

$$
E_{a}=\frac{2.303 R T_{\min } T_{\max }}{z}
$$

where $R$ means the universal gas constant $(8.314 \mathrm{~J} / \mathrm{mol} \mathrm{K}), T_{\min }$ and $T_{\max }$ are the minimum and maximum temperatures $(\mathrm{K})$ of a test range, respectively. The activation energy for thermal death of treated insects was also deduced from the Arrhenius equation. According to the Arrhenius equation, the activation energy was related to thermal death rate constant $(k)$ and absolute temperature $(1 / T)$ as follows [23]:

$$
k=k_{r e f} e^{-\frac{E_{a}}{R}\left(\frac{1}{T}-\frac{1}{T_{r e f}}\right)}
$$

where $T$ is the absolute temperature $(\mathrm{K})$, and $k_{\text {ref }}$ means the thermal death rate constant at the reference temperature $\left(T_{r e f}\right)$.

Cumulative lethal time model has been proposed to explore the lethal effect of heating up time and exposure time during the thermal treatment. The cumulative lethal effect of the thermal treatment can be calculated if the actual temperature-time history was recorded during the whole thermal treatment. For any given temperature-time history of $T(t)$, the cumulative thermal mortality of this thermal treatment can be calculated to an equivalent total lethal time, $M_{\text {ref }}(\mathrm{min})$, at a reference temperature $T_{\text {ref }}\left({ }^{\circ} \mathrm{C}\right)$ by using the following equation [23]:

$$
M_{\text {ref }}=\int_{0}^{t} 10^{\frac{T(t)-T_{r e f}}{z}} d t
$$

where $z$ is the temperature difference required for a 10 -fold change in the thermal death time curve $\left({ }^{\circ} \mathrm{C}\right)$.

The following relationship between the mortality of treated insects and the cumulated lethal time at the reference temperature of $46^{\circ} \mathrm{C}$ was derived from a 0th-order thermal death kinetic model:

$$
M(\%)=1-\left(-k \times M_{r e f}+c\right)
$$

where $M$ is the mortality (\%) of insects after thermal treatment. $k$ and $c$ are constants for the thermal death rate and at the reference temperature, respectively. 


\subsection{Statistical Analysis}

Each thermal treatment was repeated three times. The average values and standard deviations were calculated from the three replicates. All statistical analyses were carried out at a $5 \%$ significance level using variance and Tukey's honestly significant difference (HSD) test in the statistical software SPSS 16.0 version (SPSS Inc., Chicago, IL, USA). Statistical analysis of LT was based on non-overlap of 95\% confidence intervals (CI). The 95\% CI for LT of insects was predicted using commercial statistical software (Minitab 16, Minitab, Shanghai, China).

\section{Results}

\subsection{Thermal Death Kinetic Model}

The survival ratios for control adult C. pusillus, R. dominica, and T. confusum, placed in HBS at $28^{\circ} \mathrm{C}$ for 60,75 , and $150 \mathrm{~min}$, were $98.15 \pm 0.41 \%, 98.73 \pm 0.52 \%$, and $97.23 \pm 0.17 \%$, respectively, indicating that the effect of handling operation on the survival ratio of treated insects was negligible. Accordingly, the survival ratio in temperature-time treatment was not corrected by the high control survival ratio. Table 1 listed coefficients of determination $\left(R^{2}\right)$ for the survival ratio response of $C$. pusillus, $R$. dominica, and T. confusum changed with kinetic orders and treated temperatures. Owing to the largest average coefficient of determination $\left(R^{2}=0.97,0.97\right.$, and 0.96$)$ for all treated temperatures, the 0th-order kinetic model was considered as the most suitable one for C. pusillus, $R$. dominica, and T. confusum and selected for further applications.

Table 1. Determination of the suitable kinetic order (n) for the thermal death of C. pusillus, R. dominica, and T. confusum at four temperatures by comparing the coefficients of determination $\left(R^{2}\right)$.

\begin{tabular}{ccccccc}
\hline Temp. $\left({ }^{\circ} \mathbf{C}\right)$ & $N_{\mathbf{0}}$ & $\boldsymbol{n = 0}$ & $\boldsymbol{n = 0 . 5}$ & $\boldsymbol{n = 1 . 0}$ & $\boldsymbol{n = 1 . 5}$ & $\boldsymbol{n}=\mathbf{2 . 0}$ \\
\hline C. pusillus & & & & & & \\
46 & 150 & 0.98 & 0.99 & 0.92 & 0.79 & 0.66 \\
48 & 150 & 0.97 & 0.92 & 0.85 & 0.76 & 0.68 \\
50 & 150 & 0.99 & 0.96 & 0.89 & 0.80 & 0.71 \\
52 & 150 & 0.96 & 0.96 & 0.83 & 0.72 & 0.65 \\
Average & 150 & 0.97 & 0.96 & 0.87 & 0.87 & 0.67 \\
R. dominica & & & & & & \\
48 & 150 & 0.98 & 0.96 & 0.88 & 0.77 & 0.67 \\
50 & 150 & 0.98 & 0.93 & 0.83 & 0.73 & 0.64 \\
52 & 150 & 0.96 & 0.91 & 0.83 & 0.74 & 0.66 \\
54 & 150 & 0.97 & 0.88 & 0.98 & 0.97 & 0.95 \\
Average & 150 & 0.97 & 0.92 & 0.88 & 0.80 & 0.73 \\
T. confusum & & & & & & \\
46 & 150 & 0.98 & 0.91 & 0.78 & 0.65 & 0.58 \\
48 & 150 & 0.98 & 0.95 & 0.82 & 0.67 & 0.57 \\
50 & 150 & 0.93 & 0.87 & 0.80 & 0.84 & 0.65 \\
52 & 150 & 0.96 & 0.99 & 0.99 & 0.72 & 0.75 \\
Average & 150 & 0.96 & 0.93 & 0.72 & 0.75 & 0.64 \\
\hline
\end{tabular}

$N_{0}$, the initial number of insects tested.

The thermal survival curves of adult $C$. pusillus, R. dominica, and T. confusum for the most suitable 0th-order model are shown in Figure 2. The slopes of the thermal survival curves of these storage insects were reduced sharply when the treated temperature increased from $46^{\circ} \mathrm{C}$ to $52^{\circ} \mathrm{C}$ for C. pusillus, and T. confusum and $48^{\circ} \mathrm{C}$ to $54^{\circ} \mathrm{C}$ for $R$. dominica. 


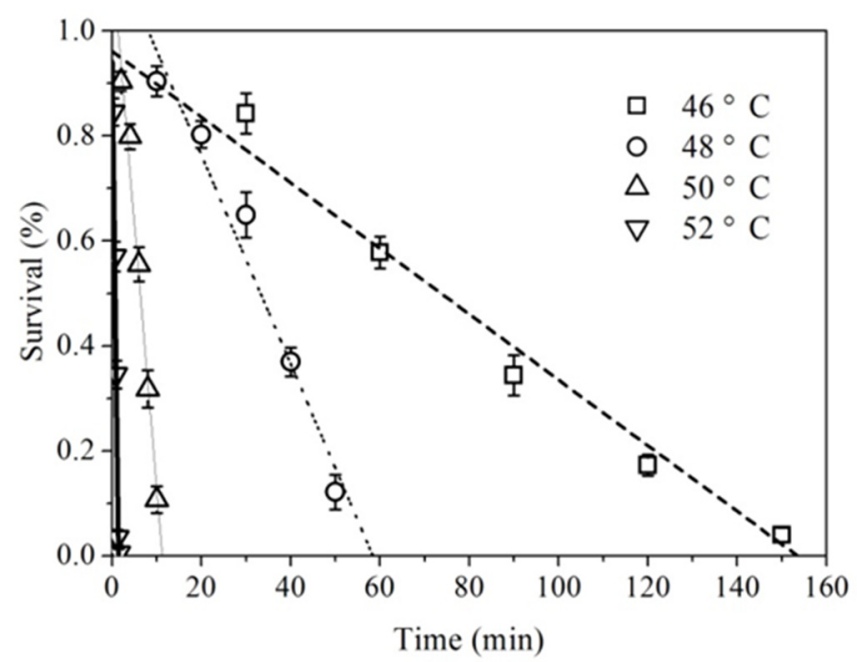

(a)

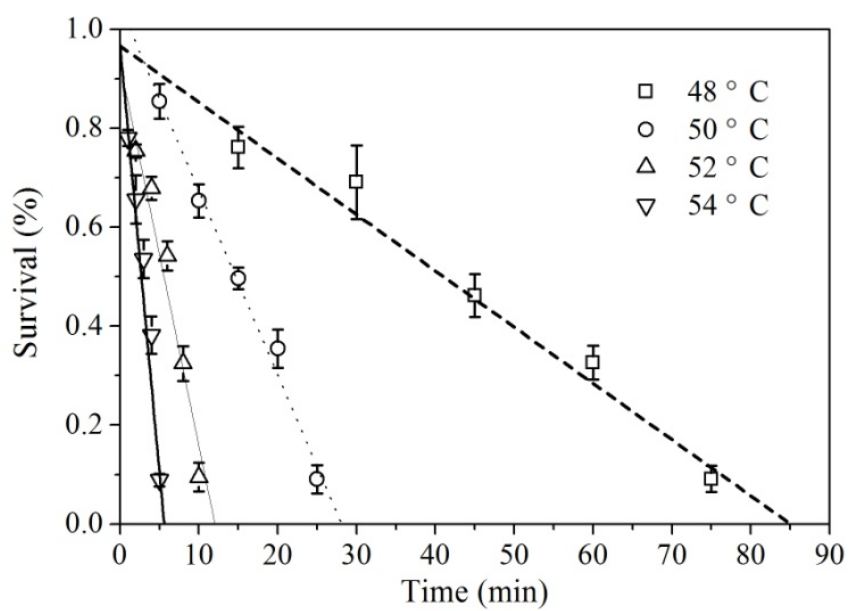

(b)

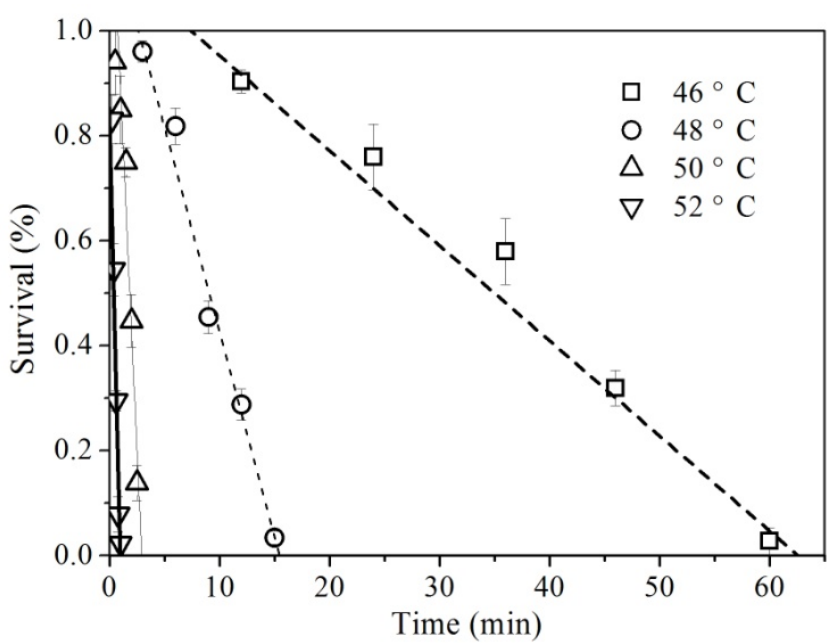

(c)

Figure 2. Thermal survival curves at different temperatures and exposure times of adult: C. pusillus (a); R. dominica (b); and T. confusum (c).

Table 2 lists the model constants obtained from the 0th-order reaction model for thermal survival ratio of C. pusillus, $R$. dominica, and T. confusum. As expected, the rate constant $(k)$ increased with 
increasing temperature for both conditions, indicating that higher temperatures required shorter exposure time to obtain the same insect mortality. For example, the minimum lethal times to obtain $100 \%$ mortality rate of 150 insects for $R$. dominica were about 75.2, 28.7, 11.7, and 5.0 min for 48, 50, 52, and $54{ }^{\circ} \mathrm{C}$, respectively.

Table 2. Thermal death constants of Oth-order reaction model for C. pusillus, R. dominica, and T. confusum at four different temperatures.

\begin{tabular}{ccc}
\hline & \multicolumn{2}{c}{$\left(\mathrm{N} / \mathrm{N}_{\mathbf{0}}\right)^{\mathbf{1 - 0}}=-\boldsymbol{k} \boldsymbol{t}+\boldsymbol{c}$} \\
\cline { 2 - 3 } Temp. $\left({ }^{\circ} \mathrm{C}\right)$ & $\boldsymbol{k}$ & $\boldsymbol{c}$ \\
\hline C. pusillus & & \\
46 & 0.01 & 0.99 \\
48 & 0.02 & 1.17 \\
50 & 0.10 & 1.16 \\
52 & 0.74 & 1.03 \\
R. dominica & & \\
48 & 0.01 & 0.98 \\
50 & 0.04 & 1.03 \\
52 & 0.08 & 0.98 \\
54 & 0.20 & 0.99 \\
T. confusum & & \\
46 & 0.02 & 1.18 \\
48 & 0.08 & 1.03 \\
50 & 0.40 & 1.03 \\
52 & 1.04 & 0.98 \\
\hline
\end{tabular}

Table 3 lists the minimum exposure time for $100 \%$ mortality of 150 insects, predicted lethal time (LT) to obtain 95\%, 99\%, and 99.99\% mortality and 95\% CI for LT of adult C. pusillus, R. dominica, and T. confusum. Lethal time increased with increasing mortality levels, but decreased with increasing exposure temperatures. When insects heated to $48^{\circ} \mathrm{C}$ with the heating rate of $5{ }^{\circ} \mathrm{C} / \mathrm{min}$, the values of $\mathrm{LT}_{95}, \mathrm{LT}_{99}$, and $\mathrm{LT}_{99.99}$ were $73.7,81.2$, and $82.0 \mathrm{~min}$ for adult $R$. dominica, respectively. Nevertheless, the values of $\mathrm{LT}_{95}$ decreased to $4.8 \mathrm{~min}$ when the exposure temperature increased to $54{ }^{\circ} \mathrm{C}$. Therefore, a short exposure time at high temperatures dramatically raised the mortality of insects.

Table 3. Comparison of LTs ( $\mathrm{min}$ ) obtained by experiments and predicted by 0th-order kinetic models for adult C. pusillus, R. dominica, and T. confusum at four different temperatures.

\begin{tabular}{cccccc}
\hline \multirow{2}{*}{ Temp. $\left({ }^{\circ} \mathbf{C}\right)$} & $N_{\mathbf{0}}$ & \multirow{2}{*}{$\begin{array}{c}\text { Min. Exposure Time for } \\
\mathbf{1 0 0 \%} \text { Mortality of 150 Insects }\end{array}$} & \multicolumn{2}{c}{ Predicted Treatment Time (min) (95\% CI) } \\
\cline { 5 - 6 } & & & $\mathbf{L T}_{\mathbf{9 5}}$ & $\mathbf{L T}_{\mathbf{9 9}}$ & $\mathbf{L T}_{\mathbf{9 9 . 9 9}}$ \\
\hline C. pusillus & & & & \\
46 & 150 & 153.3 & 158.0 & 164.7 & 166.3 \\
48 & 150 & 58.5 & $59.9(45.2-65.1)$ & $61.9(46.6-67.7)$ & $62.4(46.9-68.3)$ \\
50 & 150 & 11.1 & $11.3(9.5-11.8)$ & $11.7(9.8-12.2)$ & $11.8(9.8-12.4)$ \\
52 & 150 & 1.4 & $1.3(1.1-1.5)$ & $1.4(1.1-1.5)$ & $1.4(1.1-1.6)$ \\
R. dominica & & & & \\
48 & 150 & 75.2 & $73.7(68.8-92.7)$ & $81.2(71.4-96.9)$ & $82.0(72.1-98.3)$ \\
50 & 150 & 28.7 & $29.9(24.2-29.6)$ & $30.4(25.1-30.9)$ & $28.6(25.3-31.2)$ \\
52 & 150 & 11.7 & $11.9(8.9-13.0)$ & $12.4(9.2-13.6)$ & $12.5(9.2-13.8)$ \\
54 & 150 & 5.0 & $4.8(4.4-6.6)$ & $4.9(4.6-6.9)$ & $5.0(4.6-7.0)$ \\
T. confusum & & & & \\
46 & 150 & 62.4 & $64.9(54.5-68.1)$ & $67.1(56.1-70.6)$ & $67.9(56.6-71.3)$ \\
48 & 150 & 12.9 & $13.5(13.1-16.3)$ & $14.4(13.5-16.9)$ & $14.7(13.6-17.1)$ \\
50 & 150 & 2.6 & $2.9(2.1-3.6)$ & $3.0(2.1-3.7)$ & $3.1(2.1-3.8)$ \\
52 & 150 & 0.9 & $0.9(0.7-1.0)$ & $0.9(0.8-1.1)$ & $0.9(0.8-1.1)$ \\
\hline
\end{tabular}

$N_{0}$, the initial number of insects tested. 
The TDT curves for adult C. pusillus, R. dominica, and T. confusum are shown in Figure 3. The curves were described by the linear regression equation $\log t=18.3-0.3 \times T$ with the coefficient of determination $R^{2}=0.98$ for $C$. pusillus; $\log t=11.2-0.2 \times T$ with $R^{2}=0.99$ for $R$. dominica; and $\log t=$ $16.1-0.3 \times T$ with $R^{2}=0.99$ for $T$. confusum, where $t$ is exposure time ( $\mathrm{min}$ ) and $T$ means treatment temperature $\left({ }^{\circ} \mathrm{C}\right)$. The $z$ values deduced from the negative inverse of the slope of the TDT curve were $2.88^{\circ} \mathrm{C}, 5.18^{\circ} \mathrm{C}$ and $3.22^{\circ} \mathrm{C}$, resulting in thermal death activation energies of $689.91,380.88$ and 617.08 $\mathrm{kJ} / \mathrm{mol}$ for C. pusillus, R. dominica, and T. confusum, respectively.

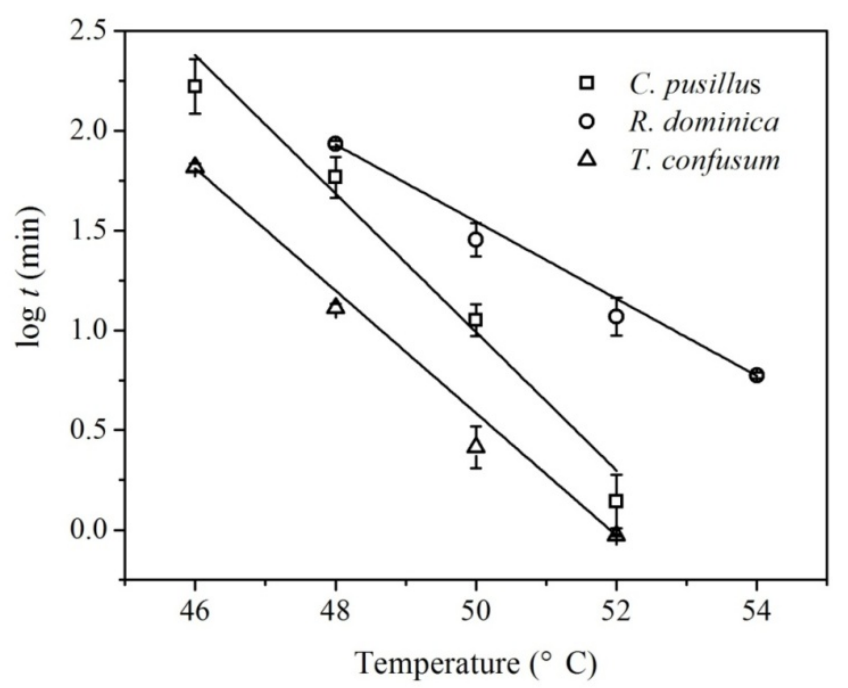

Figure 3. Thermal mortality curve for adult C. pusillus, $R$. dominica, and T. confusum at heating rate of $5{ }^{\circ} \mathrm{C} / \mathrm{min}$.

Figure 4 lists the Arrhenius graph for temperature influences on thermal death rates of adult $C$. pusillus, $R$. dominica, and T. confusum. The regression equations were $\ln k=255.8-83.4 \times 1 /(T \times 1000)$ for C. pusillus, $\ln k=140.6-46.6 \times 1 /(\mathrm{T} \times 1000)$ for $R$. dominica, and $\ln k=220.4-71.6 \times 1 /(\mathrm{T} \times 1000)$ for T. confusum. From the slope of the regression equation, the activation energy obtained by Equation (5) for C. pusillus, R. dominica, and T. confusum was 692.97, 387.07, and $595.45 \mathrm{~kJ} / \mathrm{mol}$, respectively, which agreed with that calculated by Equation (4). The activation energy of T. confusum was smaller than that for $C$. pusillus, suggesting that T. confusum was more sensitive to temperature changes than $C$. pusillus. Although R. dominica had smaller activation energy, it was more heat resistant than C. pusillus and T. confusum, since $R$. dominica was treated in a higher temperature range.

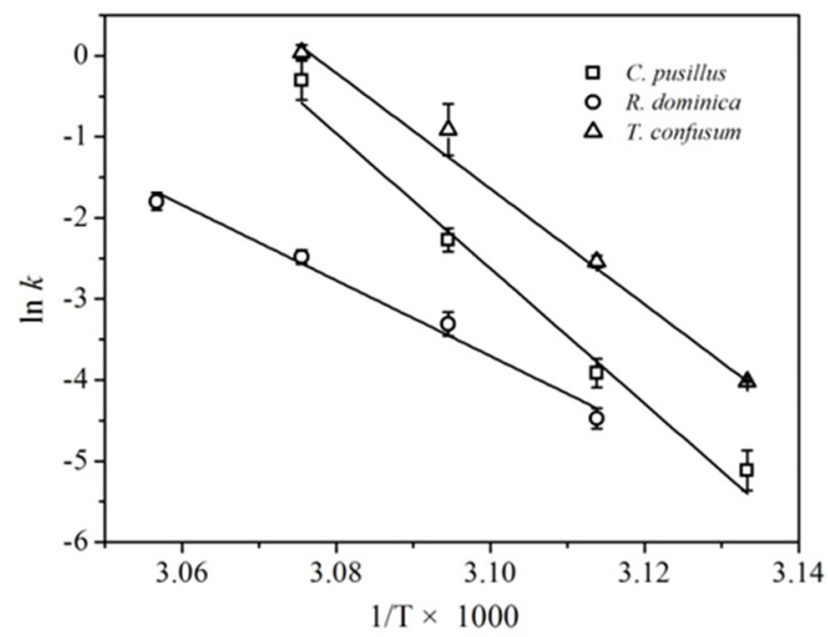

Figure 4. Arrhenius plot for temperature effects on thermal death rates of adult C. pusillus, R. dominica, and T. confusum. 


\subsection{Cumulative Lethal Time Model}

Figure 5 shows an actual temperature-time history of top and bottom blocks during thermal treatment. The temperatures of top and bottom blocks increased at a heating rate of $5^{\circ} \mathrm{C} / \mathrm{min}$ during ramp period. Once reaching the target temperatures, the temperatures of top and bottom blocks became constant during the holding period. The heating up times were 3.6, 4.0, 4.4, 4.8, and $5.2 \mathrm{~min}$ at target temperatures of $46,48,50,52$, and $54^{\circ} \mathrm{C}$, respectively.

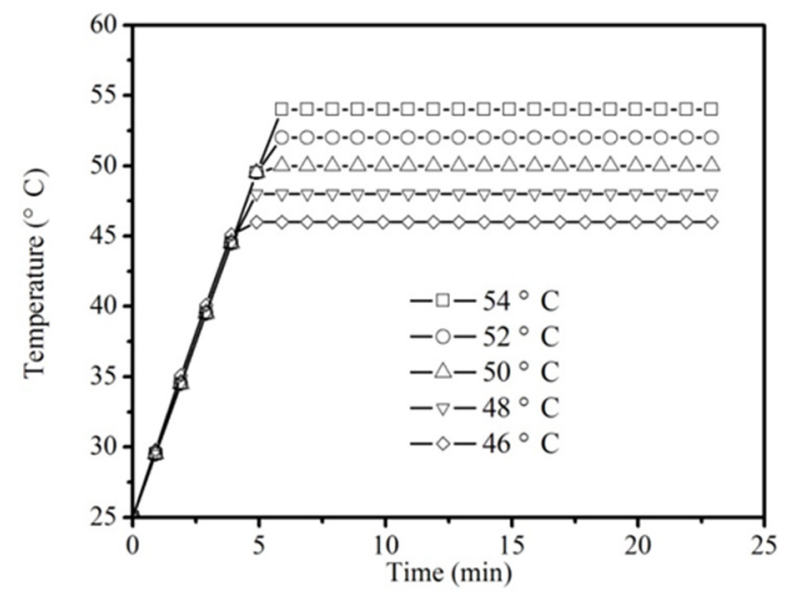

Figure 5. Temperature-time histories for the thermal treatment.

From the temperature-time curve, the cumulative lethal time $M_{\text {ref }}$ calculated from Equation (6) is shown in Figure 6. The cumulative lethal time increased slowly during ramp periods, and then increased linearly and quickly during the holding period. For example, the cumulative lethal times were $0.2,49.5,155.6$, and $261.9 \mathrm{~min}$ when the heating times were $3,6,9$, and $12 \mathrm{~min}$ at $54{ }^{\circ} \mathrm{C}$, respectively. The cumulative lethal times $M_{\text {ref }}$ at the end of ramp periods were 0.5, 1.2, 3.0, 7.2, and $17.6 \mathrm{~min}$ at 46, 48, 50,52 , and $54{ }^{\circ} \mathrm{C}$ when the reference temperature was $46^{\circ} \mathrm{C}$, respectively. According to Equation (6), the cumulative lethal times $M_{\text {ref }}$ for $T$. confusum were 63.7,66.2, 62.4, and 65.7 min when the minimum lethal times were $62.4,12.9,2.6$, and $0.9 \mathrm{~min}$ at $46,48,50$, and $52{ }^{\circ} \mathrm{C}$, respectively. Furthermore, the average cumulative lethal times $M_{\text {ref }}$ for $C$. pusillus, $R$. dominica, and T. confusum were 155.4 \pm 4.7 , $179.9 \pm 6.3$, and $64.5 \pm 1.8 \mathrm{~min}$ at $46^{\circ} \mathrm{C}$, respectively, indicating that the thermo-tolerance of these three storage insects after exposure to thermal treatment was in the following order: $R$. dominica $>$ C. pusillus $>$ T. confusum.

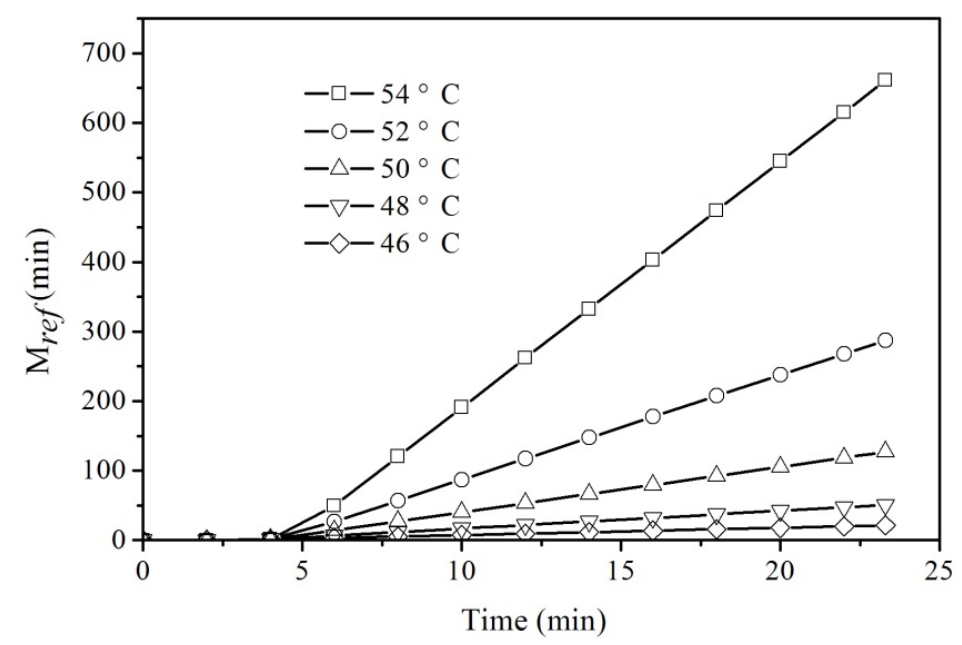

Figure 6. The cumulative lethal time $M_{\text {ref }}$ for $R$. dominica as a function of treatment time at four heating temperatures at the reference temperature of $46^{\circ} \mathrm{C}$. 
The results indicate that cumulative lethal time model could be used for predicting the mortality of insects with the help of thermal death kinetics model and the error value was less than $5 \%$. On the other hand, the cumulative lethal times $M_{\text {ref }}$ of heating up time could be calculated based on different $z$ values and were $0.327 \pm 0.004,0.501 \pm 0.002$, and $0.332 \pm 0.004 \mathrm{~min}$ for C. pusillus, $R$. dominica, and $T$. confusum, respectively. The minimum lethal times were several minutes at high temperatures or dozens of minutes at low temperatures, indicating that the effect of heat accumulation during ramp period was little for the whole lethal treatment. Moreover, the cumulative lethal times $M_{\text {ref }}$ of heating up time were almost constant for treated insects in this study. That is, the thermal death kinetic model can be used to predict the mortality of insects with considering the ramp period based on $z$ value for different insects.

\section{Discussion}

Survival ratios of adult C. pusillus, R. dominica, and T. confusum followed 0th-order kinetic reaction models. This order reaction model corresponds to that for Conogethes punctiferalis [24], S. oryzae [16], and S. zeamais [17], but contrasts with other studies using 0.5 th-order reaction model $[15,18,25,26]$. Lethal time of treated insects increased with increasing mortality levels, but decreased with increasing exposure temperatures. Similar results were found on C. pusillus and T. confusum. Exposure times for C. pusillus to obtain $95 \%$ mortality were $158.0 \mathrm{~min}$ at $46{ }^{\circ} \mathrm{C}$ but $1.3 \mathrm{~min}$ at $52{ }^{\circ} \mathrm{C}$. This may be caused by water loss and denaturing enzyme in insects at high temperatures. When the heating temperature was higher than the threshold value, cuticular permeability and water loss of insect body increased [27]. Then, ionic concentration in body fluids increased with increasing heating temperature, which accelerated the damage of cells. Pyruvate kinase, a key enzyme in glycolysis, was denatured at higher temperatures, which resulted in metabolic disorder and insect body damage or even death $[10,28,29]$. The minimum exposure time for $100 \%$ mortality of $R$. dominica reported by others was longer than observed one in this study since they heated insects with culture substrate or stored grain $[13,30]$. Due to the long minimum lethal time compared to C. pusillus and T. confusum at same treated temperatures, $R$. dominica was more thermal resistant than C. pusillus and T. confusum. Since $R$. dominica had higher $z$ value than $C$. pusillus and T. confusum, it was more heat resistant than C. pusillus and T. confusum. This result revealed by $z$ value was consistent with that indicated by the minimum exposure time.

Table 4 shows the comparison of lethal times and kinetic parameters of different storage pests reported in the literature. Most of stored pests followed the 0th-order reaction except for P. interpunctella and T. castaneum, which followed the 0.5 th-order reaction. The $k$ value of storage pests increased with increasing temperature, indicating that higher temperatures required shorter exposure time to obtain the same insect mortality. This was validated by the minimum heating time for $100 \%$ insect mortality, since it needed $61,14,3$, and $1 \mathrm{~min}$ for $T$. confusum to reach $100 \%$ mortality at $46,48,50$, and $52{ }^{\circ} \mathrm{C}$, respectively. In general, lethal temperature and exposure time of insects depended on species, developmental stage, acclimation temperature, acclimation time, heating rate, and relative humidity [10]. In Table 4 , it can be concluded that $R$. dominica is the most thermal resistant insect among the storage pests investigated because the longest lethal time $(5 \mathrm{~min})$ was needed at $54{ }^{\circ} \mathrm{C}$ to achieve $100 \%$ mortality. Due to industry-scale treatment needs high throughputs, an effective thermal treatment protocol by combining $55-60{ }^{\circ} \mathrm{C}$ with holding several minutes or higher treated temperature without holding could be developed to control insects in grains or other agriculture products. 
Table 4. Comparison of lethal times and kinetic parameters for thermal treatment between adult lesser grain borer and other storage pests.

\begin{tabular}{|c|c|c|c|c|c|c|c|c|}
\hline \multirow[t]{2}{*}{ Insect } & \multirow{2}{*}{$\begin{array}{c}\text { Temp. } \\
\left({ }^{\circ} \mathrm{C}\right)\end{array}$} & \multirow{2}{*}{$\begin{array}{l}\text { Min. Time for } 100 \% \\
\text { Mortality (min) }\end{array}$} & \multicolumn{2}{|c|}{$\begin{array}{l}\text { Thermal Death } \\
\text { Constant }\end{array}$} & \multirow{2}{*}{$\begin{array}{l}\text { Reaction } \\
\text { Order }\end{array}$} & \multirow[t]{2}{*}{$Z\left({ }^{\circ} \mathrm{C}\right)$} & \multirow{2}{*}{$\begin{array}{c}\text { Activation } \\
\text { Energy } \\
(\mathbf{k J} / \mathrm{mol})\end{array}$} & \multirow[t]{2}{*}{ Source } \\
\hline & & & $k$ & $c$ & & & & \\
\hline \multirow{4}{*}{$\begin{array}{l}\text { Cryptolestes } \\
\text { pusillus }\end{array}$} & 46 & 153 & 0.0059 & 1.1100 & \multirow{4}{*}{0} & \multirow{4}{*}{2.88} & \multirow{4}{*}{689} & \multirow{4}{*}{$\begin{array}{l}\text { This } \\
\text { study }\end{array}$} \\
\hline & 48 & 58 & 0.0149 & 1.1692 & & & & \\
\hline & 50 & 11 & 0.0788 & 1.1692 & & & & \\
\hline & 52 & 1 & 0.8192 & 1.2601 & & & & \\
\hline \multirow{4}{*}{$\begin{array}{c}\text { Plodia } \\
\text { interpunctella }\end{array}$} & 44 & 120 & 0.0078 & 1.069 & \multirow{4}{*}{0.5} & \multirow{4}{*}{3.9} & \multirow{4}{*}{514} & \multirow{4}{*}{ [15] } \\
\hline & 46 & 30 & 0.0313 & 0.963 & & & & \\
\hline & 48 & 10 & 0.0999 & 0.983 & & & & \\
\hline & 50 & 3 & 0.3595 & 1.011 & & & & \\
\hline \multirow{4}{*}{$\begin{array}{l}\text { Rhyzopertha } \\
\text { dominica }\end{array}$} & 48 & 75 & 0.0114 & 0.9784 & \multirow{4}{*}{0} & \multirow{4}{*}{5.2} & \multirow{4}{*}{381} & \multirow{4}{*}{$\begin{array}{l}\text { This } \\
\text { study }\end{array}$} \\
\hline & 50 & 29 & 0.0366 & 1.0387 & & & & \\
\hline & 52 & 12 & 0.0837 & 0.9813 & & & & \\
\hline & 54 & 5 & 0.1657 & 0.9862 & & & & \\
\hline \multirow{4}{*}{$\begin{array}{l}\text { Sitophilus } \\
\text { oryzae }\end{array}$} & 44 & 130 & 0.0069 & 1.0485 & \multirow{4}{*}{0} & \multirow{4}{*}{3.9} & \multirow{4}{*}{505} & \multirow{4}{*}{ [16] } \\
\hline & 46 & 50 & 0.0148 & 0.9913 & & & & \\
\hline & 48 & 12 & 0.0650 & 1.0235 & & & & \\
\hline & 50 & 4 & 0.2499 & 1.0560 & & & & \\
\hline \multirow{4}{*}{$\begin{array}{l}\text { Sitophilus } \\
\text { zeamais }\end{array}$} & 46 & 160 & 0.0061 & 1.0100 & \multirow{4}{*}{0} & & & \\
\hline & 48 & 40 & 0.0244 & 1.0360 & & & & \\
\hline & 50 & 14 & 0.0635 & 0.9424 & & 3.8 & 527 & [17] \\
\hline & 52 & 4 & 0.2495 & 0.9616 & & & & \\
\hline & 48 & 85 & 0.0122 & 1.0365 & & & & \\
\hline Tribolium & 50 & 12 & 0.1042 & 1.0509 & 0.5 & 2.5 & 814 & [18] \\
\hline castaneum & 52 & 2 & 0.5182 & 0.9075 & & & & \\
\hline & 46 & 62 & 0.0160 & 1.2317 & & & & \\
\hline Tribolium & 48 & 13 & 0.2898 & 1.1940 & 0 & 322 & 616 & This \\
\hline confusum & 50 & 3 & 0.0654 & 1.2438 & 0 & 3.22 & 616 & study \\
\hline & 52 & 1 & 1.0118 & 1.1361 & & & & \\
\hline
\end{tabular}

\section{Conclusions}

Survival ratios of adult $C$. pusillus, $R$. dominica, and T. confusum were influenced by different thermal treatments, including target temperature and exposure time. Survival ratios of these three storage insects followed a 0th-order kinetic reaction model. The minimum exposure times needed for achieving $100 \%$ mortality of $C$. pusillus, $R$. dominica, and T. confusum were 1.4, 5.0, and 0.9 min at 52, 54 , and $52^{\circ} \mathrm{C}$, respectively. The activation energy for controlling adult $C$. pusillus, $R$. dominica, and $T$. confusum was $689.91,380.88$, and $617.08 \mathrm{~kJ} / \mathrm{mol}$ while the $z$ value obtained from the TDT curve was 2.88, 5.18 , and $3.22{ }^{\circ} \mathrm{C}$, respectively. The thermal resistance of $R$. dominica was higher than that of C. pusillus, followed by that of T. confusum. The mortality of storage insects could be predicted by the cumulative lethal time model based on the temperature-time history during the heating process. The results of this study may provide useful information for controlling insects in stored grains and cereals.

Author Contributions: Validation, Y.W.; formal Analysis, L.H.; investigation, Y.W.; data curation, L.H.; writing-original draft preparation, L.H.; writing_-review and editing, S.W.; supervision, S.W.; and funding acquisition, S.W.

Funding: This research was funded by National Key R\&D Program of China (2016YFD0401000, 2018YFD0700100), Shaanxi Agricultural Science and Technology Innovation and Research Project (2018NY-105), and research grants from PhD research startup Northwest A\&F University (2452017196).

Conflicts of Interest: The authors declare no conflict of interest. 


\section{References}

1. Collins, P.J.; Falk, M.G.; Nayak, M.K.; Emery, R.N.; Holloway, J.C. Monitoring resistance to phosphine in the lesser grain borer, Rhyzopertha dominica, in Australia: A national analysis of trends, storage types and geography in relation to resistance detections. J. Stored Prod. Res. 2017, 70, 25-36. [CrossRef]

2. Vayias, B.J.; Athanassiou, C.G.; Kavallieratos, N.G.; Tsesmeli, C.D.; Buchelos, C.T. Persistence and efficacy of two diatomaceous earth formulations and a mixture of diatomaceous earth with natural pyrethrum against Tribolium confusum Jacquelin du Val (Coleoptera: Tenebrionidae) on wheat and maize. Pest Manag. Sci. 2006, 62, 456-464. [CrossRef] [PubMed]

3. Yang, Y.; Wilson, L.T.; Arthur, F.H.; Wang, J.; Jia, C. Regional analysis of bin aeration as an alternative to insecticidal control for post-harvest management of Sitophilus oryzae (L.) and Rhyzopertha dominica (F.). Ecol. Model. 2017, 359, 165-181. [CrossRef]

4. Yokoyama, V.Y.; Miller, G.T.; Hartsell, P.L. Evaluation of a methyl bromide quarantine treatment to control codling moth (Lepidoptera: Tortricidae) on nectarine cultivars proposed for export to Japan. J. Econ. Entomol. 1990, 83, 466-471. [CrossRef]

5. Popp, J.; Pet̋, K.; Nagy, J. Pesticide productivity and food security. A review. Agron. Sustain. Dev. 2013, 33, 243-255. [CrossRef]

6. Porto, S.M.C.; Valentia, F.; Bellac, S.; Russob, A.; Casconea, G.; Arcidiaconoa, C. Improving the effectiveness of heat treatment for insect pest control in flour mills by thermal simulations. Biosyst. Eng. 2017, 164, 189-199. [CrossRef]

7. Mahroof, R.; Subramanyam, B.; Flinn, P. Reproductive performance of Tribolium castaneum (Coleoptera: Tenebrionidae) exposed to the minimum heat treatment temperature as pupae and adults. J. Econ. Entomol. 2005, 98, 626-633. [CrossRef]

8. Mahroof, R.; Subramanyam, Bh. Susceptibility of Plodia interpunctella (Hubner) (Lepidoptera: Pyralidae) to high temperatures used during structural heat treatments. B. Entomol. Res. 2006, 97, 539-545. [CrossRef]

9. Subramanyam, B.; Mahroof, R.; Brijwani, M. Heat treatment of grain-processing facilities for insect management: A historical overview and recent advances. Stewart Postharvest Rev. 2011, 3, 1-11. [CrossRef]

10. Fields, P.G. The control of stored product insects and mites with extreme temperatures. J. Stored Prod. Res. 1992, 28, 89-118. [CrossRef]

11. Adler, C. Control of Cryptolestes pusillus (Coleoptera, Cucujidae) and Tribolium castaneum (Coleoptera, Tenebrionidae) at high temperatures. Integr. Prot. Stored Prod. 2004, 27, 209-212.

12. Kirkpatrick, R.L. Infrared radiation for control of lesser grain borers and rice weevils in bulk wheat (Coleoptera: Bostrichidae \& Curculionidae). J. Kansas Entomol. Soc. 1975, 48, 100-104.

13. Beckett, S.; Morton, R.; Darby, J. The mortality of Rhyzopertha dominica (F.) (Coleoptera: Bostrychidae) and Sitophilus oryzae (L.) (Coleoptera: Curculionidae) at moderate temperatures. J. Stored Prod. Res. 1998, 34, 363-376. [CrossRef]

14. Campolo, O.; Verdone, M.; Laudani, F.; Malacrinò, A.; Chiera, E.; Palmeri, V. Response of four stored products insects to a structural heat treatment in a flour mill. J. Stored Prod. Res. 2013, 54, 54-58. [CrossRef]

15. Johnson, J.A.; Wang, S.; Tang, J. Thermal death kinetics of fifth-instar Plodia interpunctella (lepidoptera: Pyralidae). J. Econ. Entomol. 2003, 96, 519-524. [CrossRef]

16. Yan, R.; Huang, Z.; Zhu, H.; Johnson, J.A.; Wang, S. Thermal death kinetics of adult Sitophilus oryzae and effects of heating rate on thermotolerance. J. Stored Prod. Res. 2014, 59, 231-236. [CrossRef]

17. Li, W.; Wang, K.; Chen, L.; Johnson, J.A.; Wang, S. Tolerance of Sitophilus zeamais (Coleoptera: Curculionidae) to heated controlled atmosphere treatments. J. Stored Prod. Res. 2015, 62, 52-57. [CrossRef]

18. Johnson, J.A.; Valero, K.A.; Wang, S.; Tang, J. Thermal death kinetics of red flour beetle (Coleoptera: Tenebrionidae). J. Econ. Entomol. 2004, 97, 1868-1872. [CrossRef]

19. Zhou, L.; Wang, S. Industrial-scale radio frequency treatments to control Sitophilus oryzae in rough, brown, and milled rice. J. Stored Prod. Res. 2016, 68, 9-18. [CrossRef]

20. Yu, D.; Shrestha, B.; Baik, O.-D. Radio frequency (RF) control of red flour beetle (Tribolium castaneum) in stored rapeseeds (Brassica napus L.). Biosyst. Eng. 2016, 151, 248-260. [CrossRef]

21. Hansen, J.D.; Wang, S.; Tang, J. A cumulated lethal time model to evaluate efficacy of heat treatments for codling moth Cydia pomonella (L.) (Lepidoptera: Tortricidae) in cherries. Postharvest Biol. Tec. 2004, 33, 309-317. [CrossRef] 
22. Yin, X.; Wang, S.; Tang, J.; Hansen, J.D. Thermal resistance of fifth-instar Cydia pomonella (L.) (Lepidoptera: Tortricidae) as affected by pretreatment conditioning. J. Stored Prod. Res. 2006, 42, 75-84. [CrossRef]

23. Tang, J.; Ikediala, J.N.; Wang, S.; Hansen, J.D.; Cavalieri, R.P. High-temperature-short-time thermal quarantine methods. Postharvest Biol. Tec. 2000, 21, 129-145. [CrossRef]

24. Hou, L.; Du, Y.; Johnson, J.A.; Wang, S. Thermal death kinetics of Conogethes Punctiferalis (Lepidoptera: Pyralidae) as influenced by heating rate and life stage. J. Econ. Entomol. 2015, 108, 2192-2199. [CrossRef]

25. Wang, S.; Ikediala, J.N.; Tang, J.; Hansen, J.D. Thermal death kinetics and heating rate effects for fifth-instar Cydia pomonella (L.) (Lepidoptera: Tortricidae). J. Stored Prod. Res. 2002, 38, 441-453. [CrossRef]

26. Wang, S.; Tang, J.; Johnson, J.A.; Hansenc, J.D. Thermal-death kinetics of fifth-instar Amyelois transitella (Walker) (Lepidoptera: Pyralidae). J. Stored Prod. Res. 2002, 38, 427-443. [CrossRef]

27. Gibbs, A.G. Lipid melting and cuticular permeability: New insights into an old problem. J. Insect Physiol. 2002, 48, 391-400. [CrossRef]

28. Jay, A.Y.; Denlinger, D.L. Water balance in flesh fly pupae and water vapor absorption associated with diapause. J. Exp. Biol. 1991, 157, 273-286.

29. Mutero, A.; Bride, J.-M.; Pralavorio, M.; Fournier, D. Drosophila melanogaster acetylcholinesterase: Identification and expression of two mutations responsible for cold- and heat-sensitive phenotypes. Mol. Gen. Genet. MGG 1994, 243, 699-705.

30. Boina, D.; Subramanyam, B. Relative susceptibility of Tribolium confusum life stages exposed to elevated temperatures. J. Econ. Entomol. 2004, 97, 2168-2173. [CrossRef] [PubMed]

(C) 2019 by the authors. Licensee MDPI, Basel, Switzerland. This article is an open access article distributed under the terms and conditions of the Creative Commons Attribution (CC BY) license (http://creativecommons.org/licenses/by/4.0/). 